\title{
Analysis of General Principles of Sale of Goods Law in Bangladesh
}

\author{
Mohammad Badruzzaman \\ Senior Lecturer, Department of Law, Uttara University, Dhaka, Bangladesh
}

\begin{abstract}
We are living now in a global village. All of we are world citizen. Like all other activities of life, trade and commerce crosses the boundary of boarders. There is no scope to adopt any law that may apply only within a boundary particularly in case of business. The Sale of Goods Act, 1930 is a law that deals with transfer of moveable properties or sale of goods in Bangladesh. This Act plays immense significance in trade and commerce. Though the principles relating to sale of goods are so connected with law of contract, law of negotiable instruments, law of insurance, law of carriage of goods (i,e,. sea, air, land) do not covers all other aspects in this Act. Trade and commerce has been changed in various points of view in phase of time but the concern Act is still remain untouched having a lot of lacuna to cope up with the present time. Under this Article it is tried to analyze and draw out an overall scenario of the Sale of Goods Act, 1930 to find out the solutions of problems we face in this regard.
\end{abstract}

Keywords: Contract of Sale of Goods, Condition and Warranty, Caveat Emptor, Delivery of Goods, Performance and Remedy.

\section{INTRODUCTION}

The law relating to Sale of goods in Bangladesh is dealt with the Sale of Goods Act, 1930, which came into

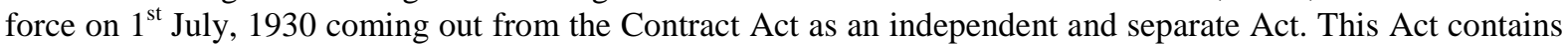
sixty-six Sections and extends to the whole Bangladesh and it is based mainly on the English Act and incorporates many of its provisions. The general provisions of the Contract Act continue to be applicable to the contract of sale of goods in so far as they are not inconsistent with the express provisions of this Act. Thus the provisions of the Contract Act relating to capacity of the parties, free consent, agreements in restraint of trade, wagering agreements and measure of damages continue to be applicable to a contract of sale of goods. The definition of consideration stands modified to the extent that in a contract of sale of goods consideration must be by way of 'price' or money consideration. A contract of sale of goods results, like any other contract, by an offer by one party and its acceptance by the other. The parties to the contract enjoy unfettered discretion to agree to any terms they like relating to delivery and payment of price as of consideration. The Sale of Goods Act does not seek to restrain this discretion. It simply lays down certain positive rules of general application for those cases where the parties have failed to contemplate expressly for contingencies which may interrupt the smooth performance of contract of sale. In some cases the Negotiable Instruments Act is concern in this regard.

\section{GENERAL PRINCIPLES AS TO FORMATION OF CONTRACT OF SALE OF GOODS}

According to the Contract Act ${ }^{1}$ defines contract as an Agreement enforceable by law is a contract. ${ }^{2}$ Therefore in a contract there must be (i) an agreement; and (ii) the agreement must be enforceable by law.

2.1. Meaning of Contract of Sale of Goods: According to the sale of goods $\mathrm{Act}^{3}$ is a contract whereby the seller transfers or agrees to transfer the property in goods to the buyer for a price. ${ }^{4}$ A contract of sale may be absolute or conditional. In an absolute sale, the property in the goods passes from the seller to the buyer immediately and nothing remains to be done by the seller. Sale on a counter in a shop is an absolute sale. In a conditional contract of Sale, the property in the goods does not pass to the buyer absolutely until a certain condition is fulfilled. The term 'Contract of Sale' is a general term and comprises of:

(I) 'Sale' and 'Agreement to Sell' where the seller transfers the property in the goods immediately to the Buyer there is a sale.

(II) But where the transfer of property in the goods is to take place at a future time or subject to some condition thereafter to be fulfilled, the contract is called an agreement to sell.

2.2. Essential Elements of a Contract of Sale of Goods: The abovementioned definition ${ }^{5}$ and relevant provisions of the Contract Act reveal the following essential characteristic of a Contract of Sale of Goods: 
2.2.1. Two Parties: The first essential is that there must be two distinct parties to a Contract of Sale, i.e., a buyer and a seller, as a person cannot buy his own goods. Thus, for example, when student of a hostel take meal with a mess run by themselves on cooperative line, there is on Contract of Sale. According to Section 4(1), there may be a contract of sale between one party-owner and another.

2.2.2. Transfer of Property: The term 'property', as used in the Sale of Goods Act, means 'general property' in goods as distinguished from 'special property' ${ }^{6}$ Transfer of property in the goods in another essential of a contract of sale of goods. Similarly, in the case of goods for the purpose of repair, the bailee has special interest in goods bailed to the extent of his labour charges.

2.2.3. Goods: A goods means every kinds of movable property other than actionable claims and money; and includes stock and shares, growing crop, grass, and thing attached to or forming part of the land which are agreed to be severed before sale or under the contract of sale."

2.2.4. Price: The consideration for a contract of sale must be money consideration called the 'Price'. If goods are sold or exchanged for other goods, the transaction is barter, governed by the Transfer of Property Act and not a sale of goods under this Act. But if goods are sold partly for goods and partly for money, the contract is one of sale.

2.2.5. Sale includes both a 'Sale' and 'an Agreement to Sell': The term 'Contract of Sale' is a generic term and includes both a 'Sale' and an 'Agreement to Sell'. Where under a contract of sale the property in the goods is immediately transferred at the time of making the contract from the seller to the buyer, the contract is called a 'Sale'. ${ }^{8}$ And where under a contract of sale the transfer of property in the goods is to take place at a future time or subject to some condition thereafter to be fulfilled ,the contract is called 'an Agreement to Sell'. 9

2.2.6. No Formalities to be observed: The Sale of Goods Act does not prescribe any particular from to constitute a valid contract of sale. ${ }^{10}$

2.2.7 .Formation Of the Contract of Sale: The contract may provide for the immediate delivery of the goods or immediate payment of the price or both or for the delivery and payment by installments or that the delivery or payment or both shall be postponed. ${ }^{11}$

2.2.8. Method of Forming the Contract: Subject to the provision of any law for the time being in force a contract of sale may be in writing, or may be implied from the conduct of the parties. ${ }^{12}$

2.3. Meaning of Goods and its kinds: The Sale of Goods Act , 1930 provides that , "goods means every kind of movable property other than actionable claims and money; and includes stock and shares, growing crops, grass, and things attached to or forming part of the land which are agreed to be severed before sale or under the Contract of Sale.'13 'Goods' form the subject- matter of a contract of sale. Goods may be classified into the following types: i.e. (I) Existing goods; (II) Future goods; and (III) Contingent goods. Existing goods are goods which are already in existence and which are physically present in some person's possession and ownership. ${ }^{14}$ Existing goods may be either (a) Specific and Ascertained or (b) Generic and Unascertained. Specific goods Are goods which can be clearly identified and recognized as separate things. The term Ascertained Goods is used in the same sense as Specific Goods. Generic Goods or Unascertained Goods are Goods indicated by description and not separately identified. They are indicated or defined only by description. i.e., if A agrees to sell to B one bag of sugar out of the lot of one hundred bags lying in his godown, it is a sale of unascertained goods because it is not known which bag is to be delivered. As soon as a particular bag is separated from the lot for delivery, it becomes ascertained or specific goods. Future goods are goods which will be manufactured or produced or acquired by the seller after the making of the contract of sale. ${ }^{15}$ There may be a contract for the sale of goods the acquisition of which by the seller depends upon a contingency which may or may not happen. ${ }^{16}$ In such cases the goods sold are called Contingent Goods. Contingent goods come within the class of future goods.

\section{GENERAL PRINCIPLES AS TO STIPULATIONS OF THE CONTRACT OF} SALE OF GOODS

A contract of sale of good contains various terms or stipulations regarding the quality of the goods, the price and the mode of its payment, the delivery of goods and its time and place. But all of them are not of equal importance. Some of these stipulations may be major terms which go to the very root of the contract their breach many frustrate the very purpose of the contract, while others may be minor terms which are not so vital that their breach may seem to be a breach of contract as such, in law of sales major terms are called 'Conditions' and minor terms are called 'Warranties'.

3.1 Condition: A condition is stipulation essential breach to the main purpose of the contract, the breach of which give rise to a right to treat the contract as repudiated. ${ }^{17}$ The definition makes it clear that condition is very 
essential for the performance of a contract. The breach of condition will be regarded as the breach of the whole contract. Conditions are terms that need to be fulfilled in order for the contract to go through. These conditions can be either written or oral and will be legally binding. In the event that the conditions set out in the agreement is not met, the party that suffers can terminate the contract, and will not be legally responsible to carry forward the sale. Meeting the set conditions is essential to the contract and, if any of the conditions that are laid out in the contract are breached (there maybe more than one conditions), that is regarded as a breach of the entire contract. For example, a company named Niloy Motors Ltd. agrees to sell 100 cars to a Corporation. However, the contract of sale includes a condition stating that Niloy Motors Ltd. will inspect the cars, verify that they are of the quality standard that was promised earlier. In the event that the cars are defective, the company can cancel the contract of sale. ${ }^{18}$

3.2 Warranty: A warranty is a guarantee that the buyer receives from the seller that all the information provided about the product is true. This could be about the product's features, functions, uses, or any other claim made about the product in general. It also refers to the terms and situations in which repairs or exchanges will be made in the event that the product does not function as originally described or intended. ${ }^{19}$ There are two types of warranties; the expressed warranty and implied warranty. An expressed warranty is when the producer makes an explicit claim about the product. i.e., Niloy Motors Ltd. may claim that the cars should remain in good working condition up to a year from its date of manufacture. An implicit claim is a claim that is not explicitly made by the seller, but is created by law and warrant that a product will be in good working condition for a reasonable amount of time and will be able to satisfy the purpose for which it was manufactured. In the event that a warranty is breached the party that suffers does not have the right to terminate the contract, instead, they can claim for damages or any inconveniences that occurred. Warranties usually have exceptions that limit the conditions in which a manufacturer will be obligated to rectify a problem. i.e., many warranties for common household items only cover the product for up to one year from the date of purchase and usually only if the product in question contains problems resulting from defective parts or workmanship. As a result of these limited manufacturer warranties, many vendors offer extended warranties. These extended warranties are essentially insurance policies for products that consumers pay for up front. Coverage will usually last for a handful of years above and beyond the manufacturer's warranty and is often more lenient in terms of limited terms and conditions. ${ }^{20}$

3.3 Condition versus Warranty: Companies frequently conduct business transactions with consumers and other firms. In order to conduct transactions in a safe manner it is important to write up a contract for sale of goods which will lay out the terms, conditions, rights, and legal implications that surround the sale. Conditions and warranties are two such components of a sale of goods contract. These components lay out the rights, implications, and terms that apply to the parties to the contract. The article that follows offers a comprehensive explanation of each term and shows how these provisions are similar and different to one another.

3.4 Difference between 'Condition' and 'Warranty': Warranties and conditions are essential to a sale of goods contract to ensure that both parties to the contract are fulfilling the claims or promises that were made in the contract. Conditions are an essential part to the contract, and in the event that conditions are not met, the party that suffers can terminate the entire sales contract. A warranty, on the other hand, is not as essential as the conditions and is a set of claims that the seller makes to the buyer about the products that are being sold. In the event that a warranty is breached, the buyer has the right to claim for damages only. In the Following way these may be enunciated-

(I) A condition has a direct link with the essential part of the contract and a warranty has no direct link with the essential part of the contract.

(II) Warranties and conditions are essential to a sale of goods contract to ensure that both parties to the contract are fulfilling the claims or promises that were made in the contract.

(III) Conditions are terms that need to be fulfilled in order for the contract to go through.

(IV) A warranty is not as essential as the conditions; it is a guarantee that the buyer receives from the seller that all the information provided about the product is true.

(V) In the event that conditions are not met, the party that suffers can terminate the entire contract, but in warranty, this does not apply; instead, the buyer has the right to claim for damages.

3.5 Implied Conditions: Conditions and Warranties are those which are included in clear words and all parties are agreeing at the time of contract. ${ }^{21}$ Those conditions are not included in the contract but the law presumes their existence in the contract is called implied conditions. Following conditions are included by law in to a contract of sale of goods-

3.5.1. The 'Right to Sell' is considered as implied condition in every sale contract. It is presumed that he can sell the goods and he can enter in sale agreement. 
3.5.2. In the case of 'Sale by Description' implied condition is that goods shall correspond with the description. A buyer can reject if the goods if these are not according the description.

3.5.3. In the case of 'Sale by Sample' goods must be supplied according the sample agreed upon condition; (i) The buyer may be able to compare the sample with the bulk; (ii) The goods should be free from any defect; (iii) The bulk should match with the quality of the sample.

3.5.4. In the case of 'Sale by Sample \& Description' goods supplied must correspond with sample and description both. So there is implied condition in it that if bulk does not match with one even then buyer may reject the goods.

3.5.5. 'Condition of Merchantable Quality' means that the goods must be sale able in the market as goods of that description are sold. In case of any defect a seller must inform the buyer. It is implied condition.

3.5.6. 'Conditions as Quality to Fitness' may be described such that sometimes buyer informs the seller that he wants to purchase the goods for particular purpose. It is implied condition that goods shall serve the purpose of buyer. As the buyer relays on the seller's skill then seller should provide the goods according the description.

3.5.7. 'Wholesomeness Condition' means conductive to health. When someone makes a sale of contract about the eatable goods this condition is applied. If someone supply the goods and it damages to health then supplier will be liable for damages.

3.5.8. 'Merchantability' means it is guaranteed to work as claimed. For instance, a vacuum cleaner that does not create enough suction to clean an average floor is in breach of the implied warranty of merchantability. "Merchantable" means the inclusion of the following criteria: (i) They must conform to the standards of the trade as applicable to the contract for sale; (ii) They must be fit for the purposes such goods are ordinarily used, even if the buyer ordered them for use otherwise; (iii) They must be uniform as to quality and quantity, within tolerances of the contract for sale; (iv) They must be packaged and labeled per the contract for sale; (v) They must meet the specifications on the package labels, even if not so specified by the contract for sale.

3.6 Implied Warranty: Warranties may be either express or implied. It is said to be express when at the will of the parties they are inserted in the contract, and they are said to be implied when the law presumes their existence in the contract automatically though they have not been put into it in express words. Implied conditions and warranties may, however, be negative or varied by express agreement, or by course of dealing between the parties, or by usage of trade. ${ }^{22}$ This provision is merely an application of the general maxim of law, 'what is expressly done puts an end what is tacit or implied. The followings are considered as implied warranty in case of transaction of sale of goods:

3.6.1. 'Possession of Goods' is an implied warranty on the part of the seller that buyer shall enjoy the quiet possession of goods sold to him without any disturbance. In case of any disturbance a buyer can claim the damages from the seller. ${ }^{23}$

3.6.2. 'Dangerous Nature of Goods Must be Disclosed' by the seller. It is necessary that seller should disclose the dangerous nature of the good sold to the buyer. If he does not disclose then any type of loss suffered by the buyer will be compensated by the seller.

3.6.3. Before selling the goods, it is necessary that these should be free from any charge or encumbrance or any kind of burden from any third party. If a sellers does not tell about such burden on the goods to the buyer and later on the buyer suffers a loss. The buyer can claim such damages from seller. ${ }^{24}$

3.7. Carefulness of the Buyer versus Doctrine of Caveat emptor: It is the duty of the buyer to be careful while purchasing goods of his requirements and in the absence of any inquiry from the buyer; the seller is not bound to disclose every defect in goods of which he may be aware. This principle corresponds with an English Doctrine 'Doctrine of Caveat Emptor.' Caveat Emptor is a principle in commerce, without a warranty the buyer takes the risk. The doctrine is a principle of property law that seeks to regulate the sale of tangible property after the closing date. The doctrine states that the buyer could not get a refund from the seller for defects on the sold property that considered the property unfit for ordinary purpose. This therefore advises buyers to take extra caution before purchasing a good without warranty. The only exception for refund is when the buyer actively concealed the defects on the items sold. This may also include the following-

(I) where the seller makes a miss-representation and buyer relies on it. Such a contract being voidable at the option of innocent party, the buyer has a right to rescind the contract.

(II) Where the seller makes a false representation, amounting to fraud and buyer relies on it, or where the seller actively conceals a defect in the goods so that so the same could not be discovered on a reasonable examination.

(III) Where the goods are purchased by description and they do not correspond with the description. 
(IV) Where the goods are purchased by description from the seller who deals in such class of goods and they are not of "merchantable quality" But the doctrine it applies, if the buyer has examined the goods, as regards defects which such examination ought to have revealed.

(V) Where the goods are bought by sample and if bulk does not correspond with the sample, or sample, or if there is any hidden or latent defect in the goods.

(VI) Where the goods are bought by sample as well as by description and the bulk does not correspond both with the sample and with the description.

(VII) Where the buyer makes known to the seller the purpose for which he requires the goods and relies upon the seller's skills and judgment but the goods supplied are unfit for the specified purpose.

(VIII) Where the trade usage attaches an implied condition or warranty as to quality and fitness and the sellers deviates from that.

\section{GENERAL PRINCIPLES AS TO TRANSFER OF OWNERSHIP OF GOODS}

Unless otherwise agreed, the goods remain at the seller's risk until the property therein is transferred to the buyer, but when the property therein is transferred to the buyer, the goods are at the buyer's risk whether delivery has been made or not. Provided that where delivery has been delayed through the fault of either buyer or seller the goods are at the risk of the party in fault as regards any loss which might not have occurred but for such fault. Provided also that nothing in this section shall affect the duties or liabilities of either seller or buyer as a bailee or custodian of the goods of the other party. ${ }^{25}$ The property in the goods is said, to be transferred from the seller to the buyer when the latter acquires the proprietary rights over the goods and the obligations linked thereto. 'Property in Goods' which means the ownership of is different from 'possession of goods' which means the physical custody or control of the goods. The transfer of property in the goods from the seller to the buyer is the essence of a contract of sale. Therefore the moment when the property in goods passes from the seller to the buyer is significant for following reasons:

(I) Ownership: The moment the property in goods passes, the seller ceases to be their owner and the buyer acquires the ownership. The buyer can exercise the proprietary rights over the goods. For example, the buyer may sue the seller for non-delivery of the goods or when the seller has resold the goods, etc.

(II) Risk follows Ownership: The general rule is that the risk follows the ownership, irrespective of whether the delivery has been made or not. If the goods are damaged or destroyed, the loss shall be borne by the person who was the owner of the goods at the time of damage or destruction. Thus the risk of loss prima facie is in the person in whom the property is.

(III) Action against Third Parties: When the goods are in any way damaged or destroyed by the action of third parties, it is only the owner of the goods who can take action against them.

(IV) Suit for Price: The seller can sue the buyer for the price, unless otherwise agreed, only after the gods have become the property of the buyer.

(V) Insolvency: In the event of insolvency of either the seller or the buyer, the question whether the goods can be taken over by the Official Receiver or Assignee, will depend on whether the property in goods is with the party who has become insolvent.

4.1. Essentials for Transfer of ownership of goods: The two essentials requirements for transfer of property in the goods are:

4.1.1. Goods must be ascertained: Unless the goods are ascertained, they (or the property therein) cannot pass from the seller to the buyer. Thus, where there is a contract for the sale of unascertained goods, no property in the goods is transferred to the buyer unless and until the goods are ascertained; and

4.1.2. Intention to Pass Property in Goods must be there: In a sale of specific or ascertained goods the property in them is transferred to the buyer at such time as the parties to the contract intend it to be regard shall be had to the terms of the contract, the conduct of the parties and the circumstances of the case.

4.2. General rules as to Transfer of existing or ascertained goods: The following rules are followed for transferring existing or ascertained goods:

4.2.1. When goods are in a deliverable state: ${ }^{26}$ where there is an unconditional contract for the sale of specific goods in a deliverable state, the property in the goods passes to the buyer when the contract is made and it is immaterial whether the time of payment on the time of delivery or both is postponed.

4.2.2. When goods have to be put into a deliverable state: ${ }^{27}$ where there is a contract for the sale of specific goods and the seller is bound to do something to the goods for the purpose of putting them into a deliverable state the property does not pass until the thing is done and the buyer that it has been done. 
4.2.3. When the goods have to be measured etc. to ascertain price: ${ }^{28}$ where there is a contract for the sale of specific goods in a deliverable state but the seller is bound to weigh, measure test or do some other act or thing with reference to the buyer has notice that it has been done.

4.2.4. When goods are delivered an approval: ${ }^{29}$ when goods are delivered to the buyer on approval or on sale or return on other similar terms the property in the goods passes to the buyer-

(a) When he signifies his approval on acceptance to the seller or does any other act adopting the transaction.

(b) If he does not signifies his approval or acceptance to the seller but retains the goods without giving notice or rejection then if a time has been fixed for the return of the goods on the expiration of that time has been fixed or the expiration of a reasonable time.

4.3. Transfer of Property in Unascertained and future goods: The general principles concerning transfer of ownership of unascertained and future goods are described under sections 18 and 25. These sections provide that where goods contracted to be sold are not ascertained or where they are future goods, the property in goods does not pass to the buyer unless and until the goods are ascertained or unconditionally appropriated to the contract so as to bring them in a deliverable state, either by the seller with the assent of the buyer or by the buyer with the assent of the seller. Such assent may be expressed or implied, and may be given either before or after the appropriation is made.

It must be kept in mind that this rule ${ }^{30}$ is fundamental in nature and it applies irrespective of what the parties intended until goods are ascertained or appropriated there is merely as curtained "agreement to sell". Sale of ten tons of paddy from a granary, has not the effect of transferring property to buyer (It is an agreement to sell only) until ten tons are appropriated to the contract by the seller and the buyer knows it.

The process of ascertainment or appropriation consists in earmarking or setting apart goods as subject-matter of the contract. It involves separating, weighing, measuring, counting or similar acts done in relation to goods with an intention to identify and determine the specific goods to be delivered under the contract. The distinction between 'ascertainment' and 'appropriation' is that whereas 'ascertainment' can be a unilateral act of the seller, that is, he alone may set apart the goods, 'appropriation' involves the element of mutual consent of the seller and the buyer.

4.3.1. Essentials of valid appropriation: As regard a valid or proper appropriation of goods, the following point should be noted:

(i) The appropriation must be of goods answering the contract description, both as to quality and quantity.

(ii) The appropriation must be intentional, i.e., it must be made with intention to appropriate goods to specific contract, and it must not be due to mere accident or mistake.

(iii) The appropriation must be made either by the seller with the assent of the buyer or by the buyer with the assent of the seller. Assent of the other future party is thus necessary; whether before of after the appropriation is made for a valid appropriation.

(iv) The appropriation must be unconditional, i.e. the seller should not reserve to himself the right of disposal of the goods until and unless certain conditions are fulfilled.

4.3.2. Delivery to Carrier: When a seller delivers the goods to a carrier or other bailee for the purpose of transmission to the buyer and does not reserve the right of disposal, the property passes on to the buyer at once. As soon as goods are loaded and railway receipt obtained and the same is sent to buyer direct the ownership is passed on delivery of goods to Railway Company. If the railway receipt is sent to banker with instructions to deliver the same on payment, the right of disposal is said to be reserved and the property will not pass to buyer at the time of delivery of goods to railway co. The delivery to the carrier may be:

(i) Absolutely for the buyer: Where the bill of lading or railway receipt is made out in the name of the buyer and is sent to him, the presumption is that no right of disposal has been reserved by the seller in respect of those goods. The ownership in such a case passes from the seller to the buyer.

(ii) Absolutely for the seller: Where the bill of lading or railway receipt is taken in the seller's or his agent's name and is sent to the agent of the seller to be delivered to the buyer on the fulfillment of certain conditions, the seller is deemed to have reserved the right of disposal of the goods. In such a case the ownership does not pass to the buyer until the necessary conditions are fulfilled and the documents of title are delivered to the buyer.

4.3.3. Reservation of Right of Disposal: ${ }^{31}$ Reservation of the right of disposal means reserving a right to dispose of the goods until certain conditions (like payment of the price) are fulfilled. When the seller reserves such a right the property in the goods does not pass until those conditions are fulfilled. The seller may reserve such a right expressly while making a contract or while making appropriation of unascertained goods. He may also reserve this right by implication, for example, when the seller while transporting goods takes the railway receipt or the bill of lading in his own name or where the seller has taken the $\mathrm{R} / \mathrm{R}$ or $\mathrm{B} / \mathrm{L}$ in the name of the buyer but has delivered the same to his bank with the instructions that the document is to be delivered to the buyer only when he makes payment of the price or accepts the bill of exchange, the right of disposal is said to be reserved impliedly. 
4.4. Rules Transfer of Title: The general rule regarding the transfer of title on sale is that 'the seller cannot transfer to the buyer of goods a better title than he himself has.' If the title of the seller is defective the buyer's title will also be subject to the same defect. The same is given in the $\mathrm{Act}^{32}$ and stated, "where goods are sold by a person who is not the owner thereof and who does not sell them under the authority or with the consent of the owner, the buyer acquires no better title to the goods than the seller had... ${ }^{33}$, this rule is expressed by the maxim, 'nemo det quod non habet,' which means that no one can give what he has not got. This rule aims at protecting the interest of the true owner and is deemed necessary in the larger interests of the society. So if a thief disposes of stolen property, the buyer acquires no title though he may have purchased the goods bonafide for value, and the real owner of the goods is entitled to recover possession of goods without paying anything to the buyer. In this sense a buyer cannot get a good title to the goods unless he purchases the goods from a person who is the owner thereof or who sells them under the authority or with the consent of the owner.

4.5. Transfer of Title by Non-Owner: The above general rule as to title is subject to the following exceptions where the buyer the buyer gets a better title to the goods than what the seller himself posses:

4.5.1. An Unauthorized Sale by a Mercantile Agent: ${ }^{34}$ A mercantile agent means an agent having in the customary course of business as such agent authority either to sell goods, or to consign goods for the purposes of sale, or to buy goods, or to raise money on the security of goods. ${ }^{35}$ Thus as a rule a mercantile agent having an authority to sell goods conveys a good title to the buyer. But by virtue of this provision ${ }^{36}$ a mercantile agent can convey a good title to the buyer even though he sells goods without having any authority from the principal to do so, provided the following conditions are satisfied:

(i) He should be in possession of the goods or documents of title to the goods in his capacity as mercantile agent and with the consent of the owner;

(ii) He should sell the goods while acting in the ordinary course of business; and

(iii) The buyer should act in good faith without having any notice, at the time of contract, that the agent has no authority to sell.

4.5.2. Transfer of Title by Estoppels: ${ }^{37}$ Sometimes the doctrine of estoppel may estop or preclude the true owner from denying seller's right to sell the goods and thus an innocent buyer may have a good title despite the want of authority of the seller. When the true owner of the goods by his conduct or words or by any act or omission leads by the buyer to believe that the seller is the owner of the goods or has the authority to sell them, he cannot afterwards deny of the seller's authority to sell. The buyer in such a case gets a better title than that of the seller. In reference to sale of goods, estoppel may arise in any of the following ways: ${ }^{38}$

(i) The owner standing by, when the seal is effected, or

(ii) Still more, by his assisting the sale, or

(iii) By permitting goods to go into the possession of another with all the insignia of possession thereof and apparent title, or

(iv) If he has otherwise acted or made representations so as to induce the buyer to alter his position to his prejudice.

4.5.3. Sale by Joint Owner: ${ }^{39}$ If one of the several joint owners of goods has the sole possession of them by permission of the co-owners, the property in the goods is transferred to any person who buys them from such joint owner in good faith without notice of the fact that the seller has no authority to sell. It may be noted that in the absence of this provision ${ }^{40}$ the buyer would have obtained only the title of the co-owners and would have become merely a co-owner with the other co-owners. Hence the provision constitutes an exception to the rule"No one can give what he has not got."

4.5.4. Sale by Person in Possession under Voidable Contract: ${ }^{41}$ When a person has obtained possession of the goods under a voidable contract and he sells those goods before the contract has been rescinded, the buyer of such goods acquires a good title to them provided the buyer acts in good faith and without notice of the seller's defect of title. The Contract $\mathrm{Act}^{42}$ also provides to the same effect when it lays down that the right to avoid a voidable contract exists only so long as the interests of a third person have not intervened. If before it is exercised the interests of a third person have intervened, i.e., the buyer has sold the goods to a sub-buyer, the latter, if acting bonafide gets a good title and the original vendor cannot claim the goods back from the subbuyer.

4.5.5. Sale by Seller in Possession after Sale: ${ }^{43}$ Where a seller, after having sold the goods, continues to be in possession of the goods or of the documents of title to them and again sells or pledges them either himself or through a mercantile agent, he will convey a good title to the buyer or the pledgee provided the buyer or the pledgee acts in good faith and without notice of the previous sale. For the application of this exception it is essential that the possession of the seller must be as seller and not as hirer that the possession of the seller must be as seller and not as hirer or bailee. 
4.5.6. Sale by Seller in Possession after "Agreement to Buy": ${ }^{44}$ Where a buyer has agreed to buy the goods and has obtained possession of the same or the documents of title to them with the consent of the seller, resells or pledges the goods either himself or through a mercantile agent, he will convey a good title to the buyer or the pledgee provided the person receiving the goods acts in good faith and without notice of any lien or other right of the original seller in respect of those goods.

4.5.7. Resale by an Unpaid Seller: ${ }^{45}$ Where an unpaid seller, who has exercised his right of lien or stoppage in transit, resells the goods the subsequent buyer acquires a good title thereto as against the original buyer, even though the resale may not be justified in the circumstances, i.e,, no notice of the resale has been given to the original buyer.

4.5.8. Some more Exceptions under other Acts of Bangladesh: Other Acts also contain some provisions under which a non-owner may pass to the buyer a better title than he himself has, such as-

(I) Sale by finder of lost goods under certain circumstances. 46

(II) Sale by pawnee or pledgee under certain circumstances. ${ }^{47}$

(III) Sale by Official Receiver or Assignee in case of insolvency of an in case of insolvency of an individual and Liquidators of companies. These persons are not owners of the properties they deal in, but convey a better title to the buyers than they themselves possess.

(IV) Under the Negotiable Instruments $\mathrm{Act}^{48}$, a holder in due courses gets a better title than what his endorser had. In other words, a person who takes a negotiable instrument in good faith and for value becomes the true owner even if he takes it from a thief or finder.

\section{GENERAL PRINCIPLES AS TO PERFORMANCE OF CONTRACT OF SALE OF GOODS}

It is the duty of the seller to deliver the goods and of the buyer to accept and pay for them, in accordance with the terms of the contract of sale. ${ }^{49}$ Thus, the performance of a contract of sale implies delivery of goods by the seller and acceptance of the delivery of good and payment for them by the buyer, in accordance with the contract. The parties are free to provide any terms the life in their contract about the time, place and manner of delivery of goods, acceptance thereof and payment of the price. But if the parties are silent and do not provide anything regarding these matters in the contract then the rules contained in the sale of Goods Act are applicable.

5.1. Delivery of goods: Delivery of goods means voluntary transfer of possession of goods form one person to another ${ }^{50}$ If transfer of possession of goods is not voluntary and Possession is obtained under pistol point or by theft. There is no delivery. Delivery of goods May be made in any of the following ways:

5.1.1. Actual delivery: Where the goods physically handed over by the seller to the buyer (or his authorized agent) the delivery is said to be actual. For example, the seller of a car hands over the car to the buyer. This is an actual delivery of the goods.

5.1.2. Symbolic delivery: Here the goods remain where they are (probably because they are bulky) but the means of obtaining possession of goods is delivered. i.e. the seller hands over to the buyer the key of the go down where the goods are stored, or transfers a document at title to the buyer which will entitle him to obtain the goods.

5.1.3. Constructive delivery or delivery by attornment: Such a delivery takes place when the person in possession of the goods of the seller ac-knowledge in accordance with the seller's order that the goods on behalf of the buyer and the buyer and the buyer has assented to it. Note that in such a delivery all the three parties. Namely, the seller the person holding the seller's goods and the buyer, Must concur For example:Where the seller hands over the delivery order to the buyer and the warehouseman.

5.2. Rules as to delivery of goods: The rules regarding delivery of goods may be are as follows:

5.2.1. Delivery May be either Actual or Symbolic or Constructive: ${ }^{51}$ Delivery of goods sold May be Made by doing anything which the parties agree shall be treated as delivery on which has the effect of putting the goods in the possession of the buyer or of any person authorized to hold them on his behalf.

5.2.2. Effect of part delivery (When property in goods is to pass on delivery): ${ }^{52}$ A delivery at part of the goods in progress of the delivery of the whole has the same effect for the purpose of passing the property in such goods as a delivery of the whole. In other words, when a delivery of part of the goods has been made with the intention of delivering the whole goods indeed.

5.2.3.Buyer to Apply for delivery: ${ }^{53}$ Although it is the duty at the seller to deliver the goods according to the contract. Yet he is not bound to deliver them until the buyer applies for delivery. It is the duty at the buyer to demand delivery. 
5.2.4.Time of delivery: ${ }^{54}$ Where under the contract at sale the seller is bound to send the goods them is fixed the seller is bound to send them within a reasonable time.

5.2.5. Place of delivery: ${ }^{55}$ The place of delivery May be stated in the contract of sale and where it is so stated the goods must be delivered at the named place during business hours on a working day. The following rules must be followed:

(i)In the case of sale the goods are to be delivered at the place at the place at which they are at the time of the sale.

(ii) In an agreement to sell, the goods are to be delivered at the place where they are at the time to the agreement to sale.

(iii) In the case of future goods the goods are to be delivered at the place at which they are manufactured on produced.

5.2.6.Delivery of goods where they are in possession of a third party: ${ }^{56}$ Where the goods at the time of sale are in the possession of a tried person there is no delivery by the seller to the buyer unless and until such third person. There is no delivery by the seller to the buyer unless and until such third person acknowledges.

5.2.7.Expenses of delivery: ${ }^{57}$ Unless otherwise agreed the expenses of and incidental to putting the goods into a deliverable state must be borne by the seller.

5.2.8. Delivery of wrong quantity or different quality: ${ }^{58}$ As already observed a seller is duty bound to deliver the goods to the buyer strictly in accordance with the terms on the contract. The goods of a different description not included in the contract, entitles the buyer: (i) to reject the whole; or (ii) to accept the whole; or (iii) to accept the quantity.

5.2.9. Installment deliveries: ${ }^{59}$ Unless otherwise agreed. The buyer of good is not bound to accept delivery thereof by installments. If the parties so agree than only the delivery of the goods May be made by installments. The answer to this question depends upon the terms of the contract and the circumstances of the case unless otherwise agreed the following two factors must be borne in mind in deciding the whole matter.

(i)The quantitative proportion which the breach bears to the contract as a whole.

(ii)The degree of probability of the repetition of the breach.

5.2.10. Delivery to carrier or wharfing: $:^{60}$ Where the seller is authorized or required to send the goods to the buyer delivery of the goods to a carrier, whether named by the buyer or not for the purpose of transmission to the buyer seller's duty, Unless the buyer requires to dispatch the goods at owner's risk it is the duty of the seller. When he delivers the goods to the carrier or where finger. To enter into a reasonable contract on behalf of the buyer for the safety of the goods.

5.2.11. Liability of buyer for neglecting on refusing to take delivery of goods: ${ }^{61}$ When the seller is ready and willing to deliver the goods and requests the buyer to take delivery and the buyer does not within a reasonable time after such request take delivery of the goods he becomes liable to the seller for any loss occasioned by his neglect on refusal to take delivery the goods.

5.3. Acceptance of delivery by buyer: The mere fact that the buyer has taken the delivery of the goods does not amount to acceptance of them. The buyer is deemed to have accepted the goods in either of the following circumstances namely: ${ }^{62}$

(i) When he intimates to the seller that he has accepted the goods. Before intimating about acceptance the buyer has right and to examine and trust the goods in order to be sure as to whether they are or not; ${ }^{63}$

(ii)When he does any act in relation to the goods which is inconsistent with the ownership of the seller, e.g., consumes, uses, pledges or resells the goods or puts his mark on them. When, after the lapse of a reasonable time, he retains the goods;

(iii)Without intimating the seller that he has rejected them. What is reasonable time is a question of fact. If time for rejection is stipulated, rejection must be within that period. It may be mentioned that on rejection of goods because of defective delivery, mere informing the seller is enough and the buyer is not bound to return the rejected goods to the seller. ${ }^{64}$

\section{GENERAL PRINCIPLES AS TO CONTRACTUAL DISPUTE AND REMEDIAL MEASURES}

A contract is formed by the concern parties with intend to perform it or to make it real. Both parties of the contract are well known about their rights, duties and liabilities regarding the contract. If any party fails to perform his own part, it is known to him what sort of liability he has to bear for such non performance. In spite of these sometimes the parties of a contract may be reluctant, or unable to perform the contract specifically. In case of contract of sale of goods it is the seller's responsibility to deliver the agreed goods to the buyer and the 
buyer is on duty to pay the price therewith. When the seller is not paid properly for the goods, being unpaid seller he is eligible to take actions against the buyer and the goods as well, and at the same time the buyer enjoys some rights against the seller for non delivery of goods to the buyer.

6.1. Unpaid Seller: Unpaid seller is the person who gives the goods to his customers on credit \& keeps the balance due; exchange of bills on some condition keeps due. The seller of goods is deemed to an unpaid seller (a) when the whole of the price has not been paid or tendered: or (b) where a bill of exchange or other negotiable instrument has been received as a conditional payment, i.e, subject to the realization thereof and the same has been dishonored. This definition emphasizes the following characteristics of an unpaid seller:

(i) He must sell goods on cash terms and not on credit, and he must be unpaid.

(ii) He must be unpaid either wholly or partly. Even if only a portion of the price, however small, remains unpaid, he is deemed to be an unpaid seller. Where the price is paid through a bill of exchange or other negotiable instrument, the same must be dishonoured.

(iii)He must not refuse to accept payment when tendered. If the price has been tendered by the buyer but the seller wrongfully refuses to take the same, he ceases to be an unpaid seller.

6.2. Rights of an Unpaid Seller: An unpaid seller has two-fold rights, i.e.,

(i) Rights of unpaid seller against the goods, and

(ii) Rights of unpaid seller against the buyer personally.

6.2.1. Rights of Unpaid Seller against the Goods: An unpaid seller has the following rights against the goods notwithstanding the fact that property in the goods has passed to the buyer:

(1) Right of lien;

(2) Right of Stoppage of goods in transit; and

(3) Right of resale.

6.2.1.1. Right of lien: ${ }^{65}$ 'Lien' is the right to retain possession of goods and refuse to deliver them to the buyer until the price due in respect of them is paid or tendered. An unpaid seller in possession of goods sold is entitled to exercise his lien on the goods in the following cases:

(a) Where the goods have been sold without any stipulation as to credit;

(b) Where the goods have been sold on credit, but the term of credit has expired:

(c) Where the buyer become insolvent, even though the period of credit may not have yet expired.

In the case of buyer's insolvency the lien exists even though goods had been sold on credit and the period of credit has not yet expired. When the goods are sold on credit the presumption is that the buyer shall keep his credit good. If, therefore, before payment the buyer becomes insolvent, the seller is entitled to exercise this right and hold the goods as security for the price. The effect of buyer's insolvency is that all stipulations as to credit are put to an end and the seller has a right to say, "I will not deliver the goods until I see that I shall get my price paid. ${ }^{66}$

6.2.1. 1.1. Lost of lien: As already observed, lien depends on physical possession of goods. Once the possession is lost, the lien is also lost. The section ${ }^{67}$ provides that the unpaid seller of goods loses his lien thereon in the following cases:

(a) when he delivers the goods to a carrier or other bailee for the purpose of transmission to the buyer without reserving the right of disposal of the goods; or

(b) when the seller expressly or his agent lawfully obtains possession of the goods; or

(c) when the seller expressly or impliedly waives his right of lien. An implied waiver takes place when the seller grants fresh term of credit or allows the buyer to accept a bill of exchange payable at a future date or assents to a sub-sale which the buyer may have made. It may be noted that right of lien, if once lost, will not revive if the buyer redelivers the goods to the seller for any particular purpose.

6.2.1.2. Rights of Stoppage of Goods in Transit: The right of stoppage in transit means the right of stopping further transit of the goods while they are with a carrier for the purpose of transmission to the buyer, resuming possession of them and retaining possession until payment or tender of the price. Thus, in a sense this right is an extension of the right of lien because it entitles the seller to regain possession even when the seller has parted with the possession of the goods.

6.2.1.3. When can this right be exercised: An unpaid seller can exercise this right only when:

(i) The buyer becomes insolvent. They buyer is said to be insolent when he has ceased to pay his debts in the ordinary course of business, or cannot pay his debts as they become due, whether he is declared an insolvent or not: ${ }^{68}$

(ii) The property has passed to the buyer. If property has not passed to the buyer then his right is termed as the "right of withholding delivery"; 69 and 
(iii) The goods are in the course of transit. This means that goods must be neither with the seller nor with the buyer nor with their agent. They should be in the custody of a carrier as an independent middleman.

6.2.1.4. Duration of transit: Since the right of stoppage in transit can be exercised only so long as the goods are in the course of transit, it becomes necessary to know as to when the transit begins and when it comes to an end. When the transit comes to an end the right of stoppage cannot be exercised. ${ }^{70}$

6.2.1.5. How right of stoppage is exercised: The unpaid seller may exercise his right of stoppage in transit either by taking actual possession of the goods, or by giving notice of his claim to the carrier or other bailee in whose possession the goods are. ${ }^{71}$

6.2.1.6. Lien and Stoppage in Transit Distinguished: The main points of distinctions between these two rights of an unpaid seller are as follows:

(i) The seller's lien attaches when the buyer is in default, whether he be solvent or insolvent. The right of stoppage in transit arises only when the buyer is insolvent.

(ii) Lien is available only when the goods are in actual possession of the seller while right of stoppage is available when the seller has parted with seller with possession and the goods are in the custody of an independent carrier.

(iii) The right of lien comes to an end once the seller hands over the possession of the goods to the carrier for the purpose of transmission to the buyer. On the other hand, the right of stoppage in transit commences after the seller has delivered the goods to a carrier for the purposes of transmission to the buyer and continues until the buyer has acquired their possession.

(iv) The right of lien consists in retaining the possession of the goods while the right of stoppage consists in regaining possession of the goods.

6.2.1.7. Effect of Sub-sale or Pledge by Buyer upon the "Two Rights of the Unpaid Seller":

The unpaid seller's right of lien or stoppage in transit is not affected by any sale or other disposition of the goods which the buyer might have made. But there are two exceptional cases when these two rights of the unpaid seller are affected by a sale or other disposition of the goods by the buyer. These exceptions are:

(i) When the seller has assented to the sale or other disposition pledge which the buyer may have made.

(ii) When a document of title to goods a bill of lading or railway receipt has been issued or transferred to a buyer, and the buyer transfers the document to a person who takes the document in good faith and for consideration.

6.2.1.8. Right of resale: ${ }^{72}$ The right of resale is a very valuable right given to an unpaid seller. In the absence of this right, the unpaid seller's other rights against the goods, namely, 'lien' and stoppage in transit,' would not have been of much use because these rights only entitle the unpaid seller to retain the goods until paid by the buyer. If the buyer continues to remain in default, then should the seller be expected to retain the goods indefinitely, especially when the goods are perishable? Obviously, this cannot be the intention of the law. Section 54, therefore, gives to the unpaid seller a limited right to resell the goods in the following cases:

(a) Where the goods are of a perishable nature; or

(b) Where such a right is expressly reserved in the contract in case the buyer should make a default; or

(c) Where the seller has given a notice to the buyer of his intention to resell and the buyer does not pay or tender the price within a reasonable time.

6.2.1.9. Sale by Auction: In the case of a sale by auction principles followed are-

(1) where goods are put up for sale in lots, each lot is prima facie deemed to be the subject of a separate contract of sale;

(2) the sale is complete when the auctioneer announces its completion by the fall of the hammer or in other customary manner; and, until such announcement is made, any bidder may retract his bid;

(3) a right to bid may be reserved expressly by or on behalf of the seller and, where such right is expressly so reserved, but not otherwise, the seller or any one person on his behalf may, subject to the provisions hereinafter contained, bid at the auction;

(4) where the sale is not notified to be subject to a right to bid on behalf of the seller, it shall not be lawful for the seller to bid himself or to employ any person to bid at such sale, or for the auctioneer knowingly to take any bid from the seller or any such person; and any sale contravening this rule may be treated as fraudulent by the buyer;

(5) the sale may be notified to be subject to a reserved or upset price;

(6) if the seller makes use of pretended bidding to raise the price, the sale is voidable at the option of the buyer. ${ }^{73}$

6.3. Rights of Unpaid Seller against the Buyer Personally: The unpaid seller has some rights that he can exercise against the buyer personally. These may be described in the following heads: 
6.3.1. Suite for price: ${ }^{74}$ Where property in goods has passed to the buyer; or where the sale price is payable 'on a day certain', although the property in goods has not passed; and the buyer wrongfully neglects or refuses to pay the price according to the terms of the contract, the seller is entitled to sue the buyer for price, irrespective of the delivery of goods.

6.3.2. Suit for damages for non-acceptance: ${ }^{75}$ Where the buyer wrongfully neglects or refuses to accept and pay for the goods, the seller may sue him for damages for non-acceptance. The seller's remedy in this case is a suit for damages rather than an action for the full price of the goods.

6.3.3. Suit for special damages and interest: ${ }^{76}$ This Section entitles the seller to use the buyer for special damages' also for such loss which the parties knew, when they made the contract, to be likely to result from the breach of it. ${ }^{77}$

6.4. Buyer's Rights against Seller: A buyer enjoys following rights against seller for non delivery of goods to him:

6.4.1. Suit for damages for non-delivery: ${ }^{78}$ Where the seller wrongfully neglects or refuses to deliver the goods to the buyer, the buyer may sue the seller for damages for non-delivery.

6.4.2. Suite for specific performance: ${ }^{79}$ Where there is breach of a contract for the sale of specific or ascertained gods, the buyer may file a suite for the specific performance of the contract.

6.4.3. Suit for damages for breach of warranty: ${ }^{80}$ Where there is breach of warranty by the seller, or where the buyer elects or is compelled to treat breach of condition as breach of warranty.

6.4.4. Suite for rescission of contract and for damages for breach of condition: ${ }^{81}$ The breach of condition entitles the buyer to treat the contract as repudiated.

6.4.5. Suite for recovery of the price together with interest: ${ }^{82}$ If the buyer has already paid the price of the goods to the seller and the goods are not delivered or they are stolen one, he can sue the seller for the refund of the price and also for the interest at reasonable rate from the date of payment to the date of refund.

\section{CONCLUSION}

The general principles of Sale of Goods Law enunciated herein are not exhaustive in nature. In almost all sections of the sale of goods Act started with 'unless otherwise agreed by the parties' imply that if the parties of the contract put any stipulation ignoring the general rules incorporated in the Act is valid. The parties of a contract of sale of goods enjoy unfettered liberty to enjoy the stipulations for putting in the contract as they like. Other relevant laws concerning sale of goods are not prohibited rather encouraged in following rules regarding sale of goods. i.e., the Law of Contract, the Law relating to Negotiable Instruments, the Law of Arbitration etc. Rules in due course of business vary from transaction to transaction, time to time and circumstances to circumstances, considering all these matter general rules are enunciated in the Sale of Goods Act. These are not compulsory for the parties in forming and performing a contract of sale of goods. The rules inserted in the Act are general in nature and these are guidelines alike for the contracting parties of the sale of goods.

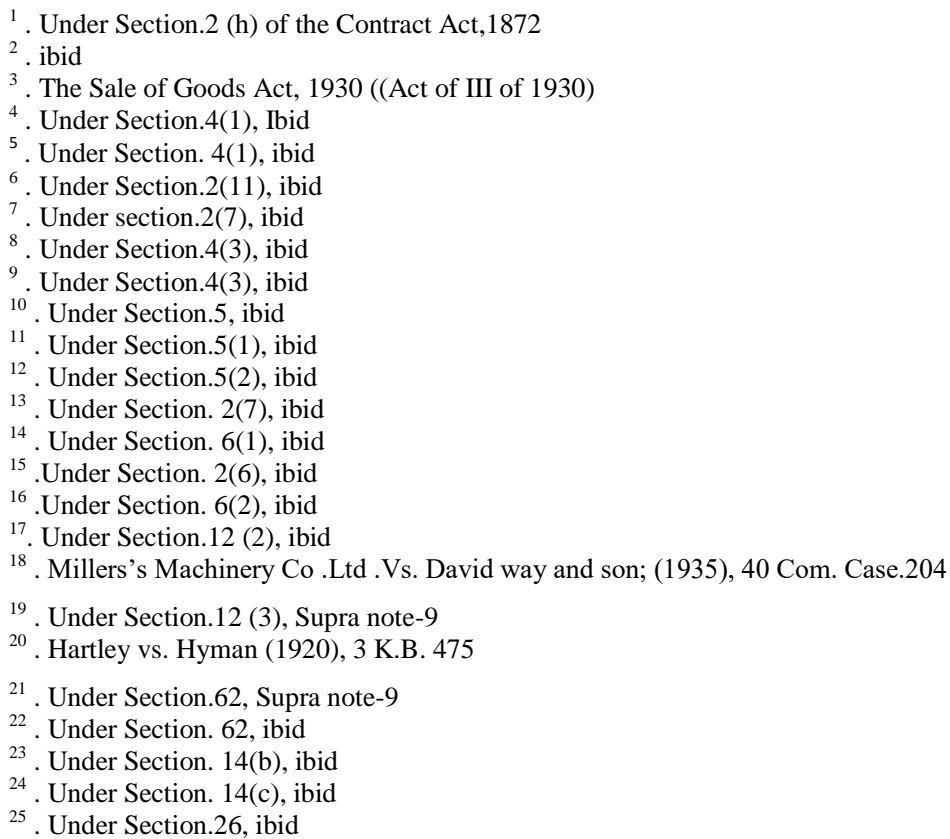


${ }^{26}$. Under Section.20, ibid

27 . Under Section.21, ibid

28 . Under Section. 22, ibid

${ }^{29}$. Under Section. 24, ibid

30. As contained in sections.18 and 25, of the Sale of Goods Act, 1930.

${ }^{31}$. Under Section.25, ibid

32 . The Sale of Goods Act, 1930.

33 . Under section.27, ibid

34 . Ibid

35 . Under Section.2(9), ibid

36 . Supra note-33

${ }^{37}$. Under Section. 27, ibid

. Pollock and Mulla: Sale of Goods Act and Partnership Act, p-120

39. Under Section.28, ibid

40 . ibid

. Under Section. 29, ibid

42. The contract Act, 1872

43 . Under Section. 30(1), Supra-7

44 . Under Section. 30(2), ibid

45 . Under Section. 54(3), ibid

46 . Under Section. 169 of The Contract Act, 1872

47 . Under Section.176, ibid

48 . The Negotiable Instruments Act, 188, (Act of XXVI of 1881)

49 . Under Section.31, The Sale of Goods Act, 1930

50. Under Section.2(2), ibid

51 . Under Section.33, ibid

52 . Under Section.34, ibid

53 . Under Section.35, ibid

54 . Under Section.36 (2) \& (4), ibid

55 . Under Section.36 (1), ibid

56 . Under Section.36 (3), ibid

57 . Under Section.36 (5), ibid

58 . Under Section.37, ibid

${ }^{59}$. Under Section.38, ibid

60. Under Section.39, ibid

61. Under Section.44, ibid

62 . Under Section.42, ibid

63 . Under Section.41, ibid

${ }^{64}$. Under Section.43, ibid

65 . Under Section. 47, ibid

${ }^{66}$. Griffiths vs. Perry, (1859), 1 E.\& E. 680

${ }^{67}$. Under Section. 49, Supra note-7

68 . Under Section.2 (8), ibid

${ }^{69}$. Under Section.46 (2), ibid

${ }^{70}$. Under Section.51, ibid

71 . Under Section.52, ibid

72 . Under Section.46(1), ibid

73 . Under Section-64, ibid

74 . Under Section.55, ibid

75 . Under Section.56, ibid

76 . Under Section.61, ibid

77 . Telu Ram Jain vs. Aggarwal \& Sons, AIR 1991 P H 140

78 . Under Section.57, Supra note-9

79 . Under Section.58, ibid

80 . Under Section.59, ibid

${ }^{81}$.Under Section.60, ibid

82 . Under Section.61, ibid

\section{REFERENCES}

[1] Atiyah, P.S., Sale of Goods, Pitman, London, 2005.

[2] Bangia, R.K.., The Sale of Goods Act, Allahbad Law Agency, Allahbad, 2015.

[3] Borrie Gordon, J., Commercial Law, Butterworths, London, 1975.

[4] Charlsworth, John; Schmitthoff, Clive Macmillan and Anthony Godwin, David.(1977). Charlesworth's Mercantile law, Stevens, London, 1977.

[5] Davar, Soharab R., Mercantile Law, Bombay : Progressive Corporation Pvt. Ltd, Bombay, 1973.

[6] Desai, T.R., Indian Contract Act, Sale of Goods Act and Partnership Act., S.C. Sarkar \& Sons Pvt. Ltd., Kolkata, 2009.

[7] Dial, Rameshwar, The Indian Sale of Goods Act, Law Publishers, Allahbad, 1930.

[8] Haque, Ekramul, The Law of Contract, Dhaka: Law Lyceum, Dhaka, 2007.

[9] https://en.wikipedia.org/wiki/Commerce, acceded May 19,2015

[10] http://moj.gov.jm/sites/default/files/laws/Sale\%20of\%20Goods.pdf, acceded May 27,2015 
[11] http://www.irishstatutebook.ie/1980/en/act/pub/0016/, acceded June 29,2015

[12] http://www.justice.gov.sk.ca/Sale-of-Goods-Act, acceded June 02,2015

[13] http://www.consumeraffairs.govt.nz/for-consumers/goods/commercial-goods, acceded May 23,2015

[14] Ivamy, E.R., Hardy, Casebook on Sale of Goods, Butterworths, London, 1980.

[15] Jhabvala, N.H., Sale of Goods Act and Indian Partnership Act, C. Jamnadass \& Company, Bombay, 2004.

[16] Kuchhal, M.C,. Mercantile Law, Vikas Publishing House Pvt. Ltd., Delhi, 1996.

[17] Mahmood, Shaukat: The Law of Arbitration; Legal Research Centre, Lahore, 1996.

[18] O.P. Sharma,O.P., A Short Commentary on Sale of Goods Act, 1930, Ashok Law House, Hyderabad, 2007.

[19] Pandia, R.H., Principles of Mercantile Law, N.M. Tripathi Pvt. Ltd., Bombay, 2005.

[20] [20]. Pllock, F., and Mulla, D.F., Indian Sale of Goods and Partnership Acts, N.M. Tripathi Pvt. Ltd., Bombay, 2014.

[21] [21]. Sen, Arun Kumar \& Mitra, Jitendra Kumar, Commercial Law, The World Press Limited, Kolkata, 2006.

[22] Singh, Avtar, Principles of Mercantile Law, Eastern Book Company, Lucknow, 2000.

[23] The Sale of Goods Act, 1930 (Act No. III of 1930)

[24] The Arbitration Act, 2001(Act No. I of 2001)

[25] The Contract Act, 1872 (Act No. IX of 1872)

[26] The Negotiable Instruments Act, 1881(Act No. XXVI of 1881)

[27] The Sale of Goods Act, 1893 (UK) 